\title{
Economics and Intercropping Indices of Sugarcane Based Intercropping System in Plant Cane
}

\author{
Shilpa V. Chogatapur*, H.T. Chandranath and R.B. Khandagave \\ Department of Agronomy, College of Agriculture, University of Agricultural Sciences, \\ Dharwad - 580 005, Karnataka, India \\ *Corresponding author
}

\section{A B S T R A C T}

A field experiment was conducted at sugarcane research farm, Zadshyapur of $\mathrm{S}$. Nijalingappa Sugar Institute (SNSI) of Belagavi which lies in northern transition zone of

Keywords

Gross returns, Net returns, B:C, LER and ATER

Article Info

Accepted:

04 July 2018

Available Online:

10 August 2018
Karnataka (Zone-8) during 2016. The experiment was laid out in split plot design with four controls outside the experiment replicated thrice. The treatments included three row spacing as main plots $(150 \mathrm{~cm}, 180 \mathrm{~cm}$ and $210 \mathrm{~cm})$, inter cropping with sugarbeet, sweet sorghum and sweet potato with 1:1 and 1:2 ratio as sub-plots with four control plots (sole sugarcane $(90 \mathrm{~cm})$, sole sugarbeet, sole sweet sorghum and sole sweet potato) outside the experiment. On the basis of results obtained from present investigation Intercropping of sugarcane $(150 \mathrm{~cm})+$ sugarbeet $1: 2$ row proportion realised significantly higher net returns (₹ 2, 46, $\left.829 \mathrm{ha}^{-1}\right)$.Sugarcane $(180 \mathrm{~cm})+$ sweet sorghum 1:1 row proportion recorded significantly higher B: C (3.24) and found at par with sugarcane $(180 \mathrm{~cm})+$ sweet sorghum 1:2 row (3.24). sugarcane $(150 \mathrm{~cm})+$ sweet potato with 1:2 row proportion recorded significantly higher LER (1.47) and found at par with sugarcane $(180 \mathrm{~cm})+$ sweet potato with 1:2 row proportion $(1.44)$. Sugarcane $(150 \mathrm{~cm})+$ Sugarbeet with 1:2 row proportion recorded significantly higher ATER (1.18)

\section{Introduction}

Sugarcane (Saccharum officinarum L.) is an important agro-industrial crop of tropical and sub-tropical regions of world and is cultivated in more than 110 countries. It is grown occupies in 26.09 million hectare with a production of 1,842 million tonnes of cane (Anon., 2016 a). Sugarcane occupies an important position in Indian agriculture and plays a pivotal role in national economy by sustaining the second largest organized agro industry in the country next to textile.
In India it is grown in an area of 4.92 million hectares with a production of 348 million tonnes and average productivity of $70.72 \mathrm{tha}^{-1}$ (Anon., 2017). Among major sugarcane growing states in India, Karnataka occupies third position in area ( 0.45 million hectares), third rank in production (3.78 million tonnes) and fifth position in productivity $\left(84.07 \mathrm{t} \mathrm{ha}^{-1}\right)$ (Anon., 2017). in recent years sugarcane farming is facing serious challenges in terms of sustainability and is severely affected by multiple factors like climate change, escalating cost of production, labour scarcity, 
slashing sugar prices in the market, declining soil health etc. There is a little scope for increasing area under sugarcane due to heavy competition for food, fiber, oilseed, pulses etc.

Therefore, the only alternative left is to increase the vertical production of sugarcane and sugar by finding out the efficient agronomic management practices. In recent years wider row planting technique (5 to 8 feet) is being popularized in tropical regions of sugarcane growing areas in India (Anon, 2013). Planting cane in wider rows helps in mechanization of several field operations viz., inter cultivation, aftercare and harvesting, thereby not only increases the efficiency but also results in reducing the cost of production.

Much of the space between two rows of sugarcane remains unutilized for an initial period of 100-120 days, because of its slow growth. Due to the wider row spacing and initial slow growth rate of sugarcane, there is ample scope for intercropping in sugarcane. Much of the space between two rows of sugarcane remains unutilized for an initial period of 100-120 days, because of its slow growth.

Due to the wider row spacing and initial slow growth rate of sugarcane, there is ample scope for intercropping in sugarcane. The major objectives of intercropping are to produce an additional crop, to optimize the use of natural resources and to stabilize the yield of crops (Willey, 1979). The space available in between the wide row can be suitably used for growing component crops for increasing the total production per unit area.

Keeping above facts in view, an investigation was carried out to study the effect of component crops in sugarcane with different row proportion for intensification of production in sugarcane based cropping system

\section{Materials and Methods}

The field experiment was conducted at sugarcane research farm, Zadshyapur of $\mathrm{S}$. Nijalingappa Sugar Institute (SNSI) of Belagavi which lies in northern transition zone of Karnataka (Zone-8) during 2016. The soil of experimental field was low in organic carbon $(0.41 \%)$ and available nitrogen $(271.2$ $\mathrm{kg} \mathrm{ha}^{-1}$ ) and medium in available phosphorus $\left(29.10 \mathrm{~kg} \mathrm{ha}^{-1}\right)$ and available potassium $\left(241.32 \mathrm{~kg} \mathrm{ha}^{-1}\right)$. The average rainfall of area was $970.8 \mathrm{~mm}$ but during 2016-17 a rainfall of $1168.2 \mathrm{~mm}$ was received. The experiment was laid out in split plot design with four controls outside the experiment replicated thrice. The treatments included three row spacing as main plots $(150 \mathrm{~cm}, 180 \mathrm{~cm}$ and $210 \mathrm{~cm})$, inter cropping with sugarbeet, sweet sorghum and sweet potato with $1: 1$ and $1: 2$ ratio as subplots with four control plots (sole sugarcane $(90 \mathrm{~cm})$, sole sugarbeet, sole sweet sorghum and sole sweet potato) outside the experiment. The crop was sown on $26^{\text {th }}$ February 2016 and harvested on $25^{\text {th }}$ January 2017.

\section{Land equivalent ratio (LER)}

It is defined as the relative land area under sole crops that is required to produce the yields obtained in intercropping at the same level of management. LER was worked out by using the following formula given by Willey (1979).

$\mathrm{LER}=\mathrm{La}+\mathrm{Lb}=\mathrm{Ya} / \mathrm{Sa}+\mathrm{Yb} / \mathrm{Sb}$

Where,

$\mathrm{La}$ and $\mathrm{Lb}=\mathrm{LER}$ for the crop ' $\mathrm{a}$ ' and ' $\mathrm{b}$ '

$\mathrm{Ya}$ and $\mathrm{Yb}=$ Individual crop yields under intercropping

$\mathrm{Sa}$ and $\mathrm{Sb}=$ Individual crop yields under sole cropping 


\section{Area time equivalent ratio (ATER)}

The limitation in the use of LER is the emphasis on the land area without consideration of time the field is dedicated to production. To correct this deficiency, the LER was modified by Hiebsch and Maccollum (1980) to include the duration of time the crop was on the land from planting to harvest. This method is known as the area time equivalent ratio (ATER). ATER was calculated by the formula evolved by Hiebsch and Maccollum (1980).

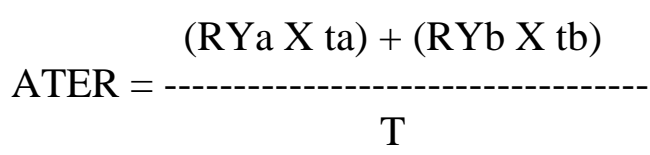

Where,

$\mathrm{RY}=$ Relative yield of species ' $a$ ' and 'b'

Yield of intercrop per hectare

RY $=$ Yield of monocrop per hectare

$\mathrm{t}=$ Duration (days) for species ' $\mathrm{a}$ ' and ' $\mathrm{b}$ '

$\mathrm{T}=$ Total duration (days) of the intercropped system

\section{Competition ratio (CRa)}

The competition ratio of two crops is given by the ratio of their respective expected relative yields. Willey and Rao (1980)

$\mathrm{CR}=\frac{\mathrm{LER}_{\mathrm{a}}}{\mathrm{LER}_{\mathrm{b}}} \times \frac{\mathrm{Z}_{\mathrm{ba}}}{\mathrm{Z}_{\mathrm{bb}}}$

\section{Aggressivity (A)}

Aggressivity of crop A with crop B gives the simple difference between the expected relative yields only. If the aggressivity value of a component crop is zero, then the two component crops are said to be equally competitive. Aggressivity values of greater than zero indicate that one crop is dominating over the other. McGillchrist and Trenbath (1971)

$\mathrm{A}_{\mathrm{ij}}=$ (Intercrop yield of crop A / Expected yield of crop A) - (Intercrop yield of crop B / Expected yield of crop B)

$A_{i j}=\frac{Y_{i j}}{Y_{i i} \times a_{i j}}-\frac{Y_{j i}}{Y_{j j} \times a_{j i}}$

System productivity parameters were analysed for 21 treatments with 4 controls outside the experiment for analysing intercropping indices, Randomised Complete Block Desgin (RCBD) with 18 treatments was used. The mean values of main plot, sub-plot and interaction effects were separately subjected to Duncan's Multiple Range Test (DMRT) using the corresponding error mean sum of squares and degrees of freedom values under $\mathrm{M}-$ STAT - C program.

\section{Results and Discussion}

Data on gross returns ( $\mathrm{Rs} \mathrm{ha}^{-1}$ ), net returns (Rs $\mathrm{ha}^{-1}$ ), and B: C ratio as influenced by different levels of row spacing, different component crops with varied row proportions and their interactions are presented in the Table 1. A row spacing of $180 \mathrm{~cm}$ recorded significantly higher gross returns (Rs 3,41,911 ha ${ }^{-1}$ ) and followed by a row spacing of $150 \mathrm{~cm}$ (Rs $3,35,695 \mathrm{ha}^{-1}$ ) in plant cane. Among the component crops in sugarcane based intercropping system, sugarcane + sugarbeet 1:2 row proportion recorded significantly higher gross returns (Rs 3,42,197 ha $\mathrm{ha}^{-1}$ ) and followed by sugarcane + sugarbeet 1:1 row proportion (Rs 3,37,782 $\mathrm{ha}^{-1}$ ) in plant cane. The interaction effect of row spacings and component crops with different row 
proportion, sugarcane $(150 \mathrm{~cm})+$ sugarbeet 1:2 row proportion recorded significantly gross returns (Rs. 3,64,242 $\mathrm{ha}^{-1}$ ) and followed by sugarcane $(150 \mathrm{~cm})+$ sugarbeet $1: 2$ row proportion ((Rs. 3,57,152 ha ${ }^{-1}$ ) in plant cane. For comparing all the treatment combinations with four controls outside the experiment, all the treatment combinations recorded significantly higher gross returns over all the controls outside the experiment in plant cane.

A row spacing of $180 \mathrm{~cm}$ recorded significantly higher net returns (Rs 2,34,303 $\mathrm{ha}^{-1}$ ) and followed by a row spacing of $150 \mathrm{~cm}$ (Rs 2,24,522 $\mathrm{ha}^{-1}$ ) in plant cane. Among the component crops in sugarcane based intercropping system, sugarcane + sugarbeet 1:2 row proportion recorded significantly higher net returns (Rs 2,31,103 ha ${ }^{-1}$ ) and followed by sugarcane + sugarbeet 1:1 row proportion (Rs 2,28,886 ha ${ }^{-1}$ ) in plant cane.

The interaction effect of row spacings and component crops with different row proportion, sugarcane $(150 \mathrm{~cm})+$ sugarbeet 1:2 row proportion recorded significantly net returns (Rs. 2,46,829 $\mathrm{ha}^{-1}$ ) and followed by sugarcane $(150 \mathrm{~cm})+$ sugarbeet $1: 2$ row proportion ((Rs. 2,41,869 ha ha $^{-1}$ in plant cane. For comparing all the treatment combinations with four controls outside the experiment, all the treatment combinations recorded significantly higher net returns over all the controls outside the experiment in plant cane.

A row spacing of $180 \mathrm{~cm}$ recorded significantly higher B: C (3.18) and followed by a row spacing of $210 \mathrm{~cm}$ (3.03) in plant cane. Among the component crops in sugarcane based intercropping system, recorded significantly higher B:C (3.14) and found at par with sugarcane + sweet sorghum 1:2 row proportion (3.14) and followed by sugarcane + sugarbeet 1:1 row proportion in plant cane. The interaction effect of row spacings and component crops with different row proportion, sugarcane $(180 \mathrm{~cm})+$ sweet sorghum 1:1 row proportion recorded significantly higher B:C (3.24) and found at par with sugarcane $(180 \mathrm{~cm})+$ sweet sorghum 1:2 row (3.24). Lowest B: C was recorded by sugarcane $(150 \mathrm{~cm})+$ sweet potato 1:1 row proportion in plant cane. For comparing all the treatment combinations with four controls outside the experiment, all the treatment combinations recorded significantly higher B: $\mathrm{C}$ over all the controls outside the experiment in plant cane.

The data computed on intercropping indices like Land equivalent ratio (LER), Area time equivalent ratio (ATER), Aggressivity and Competition ratio due to varied levels of row spacing, different component crops with varied row proportions and their interactions are presented in Table 2. In plant cane, among treatments, sugarcane $(150 \mathrm{~cm})+$ sweet potato with 1:2 row proportion recorded significantly higher LER (1.47) and found at par with sugarcane $(180 \mathrm{~cm})+$ sweet potato with 1:2 row proportion (1.44). Lowest LER (1.11) was recorded by sugarcane $180(\mathrm{~cm})+$ sugarbeet with 1:1 row proportion. Sugarcane $(150 \mathrm{~cm})$ + Sugarbeet with 1:2 row proportion recorded significantly higher ATER (1.18) and followed by sugarcane $(180 \mathrm{~cm})+$ sugarbeet with 1:2 row proportion (1.13). Lowest ATER (0.92) was recorded by sugarcane $(150 \mathrm{~cm})+$ sweet potato with 1:1 row proportion. Among the treatments significantly higher aggressivity (1.76) in sugarcane was recorded by sugarcane $(210 \mathrm{~cm})+$ sugarbeet with 1:1 row proportion and found at par with sugarcane $(180 \mathrm{~cm})+$ sugarbeet with 1:1 row proportion (1.68) and sugarcane $(150 \mathrm{~cm})+$ sugarbeet 1:1 row proportion (1.65). The lowest agrresivity was recorded by sugarcane $(150 \mathrm{~cm})+$ sweet potato 1:2 row proportion. Aggressivity of component crop significantly differed due to interactions of different levels of row spacing and different component crops with varied row proportions. 
Table.1 Economics of sugarcane system as influenced by different row spacing and intercrops

\begin{tabular}{|c|c|c|c|c|c|c|c|c|c|c|c|c|}
\hline \multirow{3}{*}{$\begin{array}{l}\text { Treatment } \\
\text { Intercrops } \\
\text { with row } \\
\text { proportions } \\
\text { (I) } \\
\end{array}$} & \multicolumn{4}{|c|}{ Gross returns (Rs ha $\left.{ }^{-1}\right)$} & \multicolumn{4}{|c|}{ Net returns (Rs ha $\left.{ }^{-1}\right)$} & \multicolumn{4}{|c|}{$\mathrm{B}: \mathrm{C}$} \\
\hline & \multicolumn{12}{|c|}{ Row spacing (S) } \\
\hline & $\begin{array}{l}\text { S1 } \\
150 \mathrm{~cm}\end{array}$ & $\begin{array}{l}\mathrm{S} 2 \\
180 \mathrm{~cm}\end{array}$ & $\begin{array}{l}\mathrm{S3} \\
210 \mathrm{~cm}\end{array}$ & Mean & $\begin{array}{l}\text { S1 } \\
150 \mathrm{~cm}\end{array}$ & $\begin{array}{l}\text { S2 } \\
180 \mathrm{~cm}\end{array}$ & $\begin{array}{l}\mathrm{S3} \\
210 \mathrm{~cm}\end{array}$ & Mean & $\begin{array}{l}S 1 \\
150 \mathrm{~cm}\end{array}$ & $\begin{array}{l}\mathrm{S2} \\
180 \mathrm{~cm}\end{array}$ & $\begin{array}{l}\mathrm{S3} \\
210 \mathrm{~cm}\end{array}$ & Mean \\
\hline $\begin{array}{l}I_{1: S . C+S . B} \\
1: 1\end{array}$ & $3,57,152 b$ & $3,49,636 \mathrm{~cd}$ & 306558hi & 337782b & $241869 b c$ & $239803 b-d$ & 204923gh & $228865 b$ & $3.10 c-e$ & $3.18 b$ & $3.02 \mathrm{f}$ & $3.10 b c$ \\
\hline $\begin{array}{l}\mathrm{I}_{2:} \mathrm{S} . \mathrm{C}+\mathrm{S} . \mathrm{B} \\
1: 2\end{array}$ & $3,64242 \mathrm{a}$ & $3,52,807 \mathrm{c}$ & $309542 \mathrm{~h}-\mathrm{j}$ & 342197a & $2,46,829 a$ & 240649de & $205833 \mathrm{~h}$ & 231103a & $3.10 \mathrm{c}-\mathrm{e}$ & $3.15 b c$ & $2.98 \mathrm{~b}$ & $3.08 c$ \\
\hline $\begin{array}{l}\mathrm{I}_{3:} \mathrm{S} . \mathrm{C}+\mathrm{S} . \mathrm{S} \\
1: 1\end{array}$ & $3,44,968 \mathrm{e}$ & 344481e f & 304962ij & 331470c & $233422 \mathrm{e}$ & 238158b-d & $206397 \mathrm{gh}$ & 225992c & $3.09 \mathrm{de}$ & $3.24 \mathrm{a}$ & 3.09de & $3.14 a$ \\
\hline $\begin{array}{l}\mathrm{I}_{4:} \mathrm{S} . \mathrm{C}+\mathrm{S} . \mathrm{S} \\
1: 2\end{array}$ & $3,42,497 \mathrm{~g}$ & 346341 ef & $309646 j$ & 332828d & $230485 f$ & 239486e & $210775 \mathrm{~h}$ & 226915d & $3.06 \mathrm{ef}$ & $3.24 \mathrm{a}$ & $3.13 b$ & $3.14 a$ \\
\hline $\begin{array}{l}\mathbf{I}_{5:} \text { S.C }+ \text { S.P } \\
1: 1\end{array}$ & $2,95,385 \mathrm{k}$ & $331965 \mathrm{~g} \mathrm{~h}$ & $289591 \mathrm{k}$ & $305647 \mathrm{e}$ & $189682 \mathrm{j}$ & $227108 f$ & 191801i & $202863 e$ & $2.79 \mathrm{i}$ & $3.17 \mathrm{~b}$ & $2.96 f g$ & $2.97 d$ \\
\hline $\begin{array}{l}I_{6:} S . C+S . P \\
1: 2\end{array}$ & $2,93,6701$ & $325080 \mathrm{gh}$ & $293864 k$ & $304205 \mathrm{fe}$ & $188622 \mathrm{k}$ & 219573gh & $195289 \mathrm{ij}$ & 201161f & $2.80 \mathrm{i}$ & $3.08 \mathrm{de}$ & $2.98 \mathrm{gh}$ & $2.95 d$ \\
\hline $\mathrm{I}_{7:}$ Sole S.C & $3,51,950 \mathrm{a}$ & $343067 \mathrm{e}$ & $302900 \mathrm{k}$ & $332639 b c$ & $240746 b$ & $235341 \mathrm{ab}$ & $202670 \mathrm{~g}$ & $226253 a$ & $3.16 \mathrm{~b}$ & $3.18 \mathrm{a}$ & $3.02 \mathrm{fg}$ & 3.12ab \\
\hline $\begin{array}{l}\text { Sole S.C } \\
(90 \mathrm{~cm})\end{array}$ & $2,61,250$ & & & & $1,44,523$ & & & & 2.24 & & & \\
\hline Sole S.B & 48750 & & & & 15774 & & & & 1.48 & & & \\
\hline \begin{tabular}{|l|} 
Sole S.S \\
\end{tabular} & 42240 & & & & 19509 & & & & 1.86 & & & \\
\hline Sole S.P & 37975 & & & & 14914 & & & & 1.65 & & & \\
\hline \begin{tabular}{|l} 
Mean of \\
main plot
\end{tabular} & $335695 b$ & 341911a & $302438 c$ & & $224522 b$ & 234303a & 202527c & & 3.02b & 3.18a & $3.03 b$ & \\
\hline $\begin{array}{l}\text { Mean with } \\
\text { control } \\
\end{array}$ & 290021 & & & & 192967 & & & & 2.87 & & & \\
\hline \begin{tabular}{|l|} 
Sources \\
\end{tabular} & \multicolumn{2}{|c|}{ S.Em \pm} & \multicolumn{2}{|c|}{ C.D. } & \multicolumn{2}{|c|}{ S.Em \pm} & \multicolumn{2}{|c|}{ C.D. } & \multicolumn{2}{|c|}{ S.Em \pm} & \multicolumn{2}{|c|}{ C.D. } \\
\hline $\begin{array}{l}\text { Row spacing } \\
\text { (S) }\end{array}$ & \multicolumn{2}{|l|}{2643} & \multicolumn{2}{|l|}{-} & \multicolumn{2}{|l|}{2643} & \multicolumn{2}{|l|}{-} & \multicolumn{2}{|l|}{0.03} & \multicolumn{2}{|l|}{-} \\
\hline $\begin{array}{l}\text { Inter crop } \\
\text { ratio (I) } \\
\end{array}$ & \multicolumn{2}{|l|}{1181} & \multicolumn{2}{|l|}{ - } & \multicolumn{2}{|l|}{1181} & \multicolumn{2}{|l|}{-} & \multicolumn{2}{|l|}{0.01} & \multicolumn{2}{|l|}{ - } \\
\hline$S \times I$ & \multicolumn{2}{|l|}{2045} & \multicolumn{2}{|l|}{-} & \multicolumn{2}{|l|}{2045} & \multicolumn{2}{|l|}{ - } & \multicolumn{2}{|l|}{0.02} & \multicolumn{2}{|l|}{-} \\
\hline Control & \multicolumn{2}{|l|}{4158} & \multicolumn{2}{|l|}{11822} & \multicolumn{2}{|l|}{4158} & 11822 & & 0.03 & & 0.09 & \\
\hline
\end{tabular}

S.C: Sugarcane, S.B: Sugarbeet, S.S: Sweet sorghum, S.P: Sweet potato

Means followed by the same letter (s) within a column are not significantly differed by DMRT $(\mathrm{P}=0.05)$ 
Table.2 Intercropping indices of sugarcane based intercropping system in plant cane

\begin{tabular}{|c|c|c|c|c|c|c|}
\hline Treatments & LER & ATER & $\begin{array}{l}\text { Competiti } \\
\text { on ratio } \\
\text { for } \\
\text { sugarcane }\end{array}$ & $\begin{array}{l}\text { Competi } \\
\text { tion ratio } \\
\text { for } \\
\text { compone } \\
\text { nt crop }\end{array}$ & $\begin{array}{l}\text { Aggress } \\
\text { ivity for } \\
\text { sugarca } \\
\text { ne }\end{array}$ & $\begin{array}{l}\text { Aggressiv } \\
\text { ity for } \\
\text { compone } \\
\text { nt crop }\end{array}$ \\
\hline $\begin{array}{l}\text { I : Sugarcane } 150+\text { Sugarbeet } \\
\text { with 1:1 row proportion }\end{array}$ & $1.16 \mathrm{ef}$ & $1.07 \mathrm{~d}$ & $3.03 \mathrm{bc}$ & $0.34 \mathrm{gh}$ & $1.65 \mathrm{bc}$ & $-1.65 \mathrm{ij}$ \\
\hline $\begin{array}{l}\text { I2: Sugarcane } 150+\text { Sugarbeet } \\
\text { with 1:2 row proportion }\end{array}$ & $1.38 \mathrm{~b}$ & $1.18 \mathrm{a}$ & $1.64 \mathrm{~d}-\mathrm{h}$ & $0.61 \mathrm{~d}$ & $1.36 \mathrm{ef}$ & $-1.36 \mathrm{~d}-\mathrm{h}$ \\
\hline $\begin{array}{l}\text { I }_{3:} \text { Sugarcane } 150+\text { Sweet } \\
\text { sorghum with 1:1 row proportion }\end{array}$ & $1.20 \mathrm{~d}-\mathrm{f}$ & $1.02 \mathrm{fg}$ & $1.89 \mathrm{~d}-\mathrm{g}$ & $0.53 \mathrm{e}$ & $1.40 \mathrm{e}$ & $-1.40 \mathrm{e}-\mathrm{i}$ \\
\hline $\begin{array}{l}\mathrm{I}_{4} \text { : Sugarcane } 150+\text { Sweet } \\
\text { sorghum with 1:2 row proportion }\end{array}$ & $1.37 \mathrm{~b}$ & 1.04 ef & $1.35 \mathrm{e}-\mathrm{h}$ & $0.75 \mathrm{c}$ & $1.15 \mathrm{~h}$ & $-1.15 c-e$ \\
\hline $\begin{array}{l}\text { I5: Sugarcane } 150+\text { Sweet potato } \\
\text { with 1:1 row proportion }\end{array}$ & $1.17 \mathrm{ef}$ & $0.92 \mathrm{i}$ & $1.06 \mathrm{gh}$ & $0.94 \mathrm{~b}$ & $0.85 \mathrm{j}$ & $-0.85 b$ \\
\hline $\begin{array}{l}\text { I6: Sugarcane } 150+\text { Sweet potato } \\
\text { with 1:2 row proportion }\end{array}$ & $1.47 \mathrm{a}$ & $0.99 \mathrm{~h}$ & $0.70 \mathrm{~h}$ & $1.42 \mathrm{a}$ & $0.44 \mathrm{k}$ & $-0.44 \mathrm{a}$ \\
\hline $\begin{array}{l}\text { I7: Sugarcane } 180+\text { Sugarbeet } \\
\text { with 1:1 row proportion }\end{array}$ & $1.15 \mathrm{fg}$ & $1.07 \mathrm{~d}$ & $3.34 \mathrm{~b}$ & $0.31 \mathrm{~h}$ & $1.68 \mathrm{~b}$ & $-1.68 \mathrm{ij}$ \\
\hline $\begin{array}{l}\text { I8: Sugarcane } 180+\text { Sugarbeet } \\
\text { with 1:2 row proportion }\end{array}$ & $1.28 \mathrm{c}$ & $1.13 \mathrm{~b}$ & $2.25 \mathrm{c}-\mathrm{f}$ & $0.45 \mathrm{f}$ & $1.53 \mathrm{~d}$ & $-1.53 \mathrm{f}-\mathrm{j}$ \\
\hline $\begin{array}{l}\text { I: Sugarcane } 180+\text { Sweet } \\
\text { sorghum with 1:1 row proportion }\end{array}$ & $1.19 \mathrm{~d}-\mathrm{f}$ & $1.04 \mathrm{ef}$ & $2.34 \mathrm{c}-\mathrm{e}$ & $0.43 \mathrm{f}$ & $1.54 \mathrm{~d}$ & $-1.54 f-j$ \\
\hline $\begin{array}{l}\mathrm{I}_{10} \text { Sugarcane } 180+\text { Sweet } \\
\text { sorghum with 1:2 row proportion }\end{array}$ & $1.37 \mathrm{~b}$ & $1.07 \mathrm{~d}$ & $1.57 \mathrm{e}-\mathrm{h}$ & $0.64 \mathrm{~d}$ & $1.30 \mathrm{fg}$ & $-1.30 \mathrm{~d}-\mathrm{g}$ \\
\hline $\begin{array}{l}\mathrm{I}_{11:} \text { Sugarcane } 180+\text { Sweet potato } \\
\text { with } 1: 1 \text { row proportion }\end{array}$ & $1.23 \mathrm{~d}$ & $1.03 \mathrm{e}-\mathrm{g}$ & $1.56 \mathrm{e}-\mathrm{h}$ & $0.64 \mathrm{~d}$ & $1.27 \mathrm{~g}$ & $-1.27 \mathrm{~d}-\mathrm{f}$ \\
\hline $\begin{array}{l}I_{12:} \text { Sugarcane } 180+\text { Sweet potato } \\
\text { with 1:2 row proportion }\end{array}$ & $1.44 \mathrm{a}$ & $1.07 \mathrm{~d}$ & $1.05 \mathrm{gh}$ & $0.95 \mathrm{~b}$ & $0.93 \mathrm{i}$ & $-0.93 b c$ \\
\hline $\begin{array}{l}\mathrm{I}_{13} \text { : Sugarcane } 210+\text { Sugarbeet } \\
\text { with 1:1 row proportion }\end{array}$ & $1.11 \mathrm{~g}$ & $1.05 \mathrm{de}$ & $4.92 \mathrm{a}$ & $0.23 \mathrm{i}$ & $1.76 \mathrm{a}$ & $-1.76 \mathrm{j}$ \\
\hline $\begin{array}{l}\text { I }_{14} \text { Sugarcane } 210+\text { Sugarbeet } \\
\text { with 1:2 row proportion }\end{array}$ & $1.21 \mathrm{de}$ & $1.10 \mathrm{c}$ & $3.03 \mathrm{bc}$ & $0.34 \mathrm{gh}$ & $1.64 \mathrm{bc}$ & $-1.64 h-j$ \\
\hline $\begin{array}{l}I_{15} \text { Sugarcane } 210+\text { Sweet } \\
\text { sorghum with 1:1 row proportion }\end{array}$ & $1.17 \mathrm{ef}$ & $1.03 \mathrm{e}-\mathrm{g}$ & $2.60 \mathrm{~b}-\mathrm{d}$ & $0.39 \mathrm{fg}$ & $1.58 \mathrm{~cd}$ & $-1.58 \mathrm{~g}-\mathrm{j}$ \\
\hline $\begin{array}{l}\text { I16: Sugarcane } 210+\text { Sweet } \\
\text { sorghum with 1:2 row proportion }\end{array}$ & $1.35 \mathrm{~b}$ & $1.07 \mathrm{~d}$ & $1.66 \mathrm{~d}-\mathrm{h}$ & $0.60 \mathrm{de}$ & $1.35 \mathrm{e}-\mathrm{g}$ & $-1.35 \mathrm{~d}-\mathrm{g}$ \\
\hline $\begin{array}{l}\text { I }_{17} \text { Sugarcane } 210+\text { Sweet potato } \\
\text { with } 1: 1 \text { row proportion }\end{array}$ & $1.17 \mathrm{ef}$ & $1.01 \mathrm{gh}$ & $1.89 \mathrm{~d}-\mathrm{g}$ & $0.53 \mathrm{e}$ & $1.36 \mathrm{ef}$ & $-1.36 \mathrm{~d}-\mathrm{h}$ \\
\hline $\begin{array}{l}\text { I }_{18} \text { Sugarcane } 210+\text { Sweet potato } \\
\text { with } 1: 2 \text { row proportion }\end{array}$ & $1.39 \mathrm{~b}$ & $1.07 \mathrm{~d}$ & $1.25 \mathrm{f}-\mathrm{h}$ & $0.80 \mathrm{c}$ & $1.09 \mathrm{~h}$ & $-1.09 b-d$ \\
\hline S.Em \pm & 0.02 & 0.01 & 0.30 & 0.02 & 0.03 & 0.03 \\
\hline
\end{tabular}


In plant cane, significantly higher aggressivity $(-0.44)$ in component crop was recorded by sugarcane $(150 \mathrm{~cm})+$ sweet potato with $1: 2$ row proportion and followed by sugarcane $(150 \mathrm{~cm})+$ sweet potato with $1: 1$ row proportion. The lowest aggressivity $(-1.76)$ in component crop was recorded by sugarcane $(210 \mathrm{~cm})+$ sugarbeet with $1: 1$ row proportion.

Competition ratio of sugarcane significantly differed due to interactions of different levels of row spacing and different component crops with varied row proportions. In plant cane, significantly higher competition ratio (4.92) in sugarcane was recorded by sugarcane (210 $\mathrm{cm})+$ sugarbeet with 1:1 row proportion and followed by sugarcane $(180 \mathrm{~cm})+$ sugarbeet with 1:1 row proportion. The lowest competition ratio (0.77) in sugarcane was recorded by sugarcane $(150 \mathrm{~cm})+$ sweet potato with 1:2 row proportion. Significantly higher competition ratio (1.42) in component crop was recorded by sugarcane $150+$ sweet potato with 1:2 row proportion and followed by sugarcane $(150 \mathrm{~cm})+$ sweet potato with 1:1 row proportion. The lowest competition ratio (0.23) in component crop was recorded by sugarcane $(210 \mathrm{~cm})+$ sugarbeet with $1: 1$ row proportion. In ratoon cane, similar trend was followed as that of plant cane.

Intercropping of sugarcane $(150 \mathrm{~cm})+$ sugarbeet 1:2 row proportion realised significantly higher net returns ( $₹$ 2, 46, 829 ha $\left.^{-1}\right)$.Sugarcane $(180 \mathrm{~cm})+$ sweet sorghum $1: 1$ row proportion recorded significantly higher B:C (3.24) and found at par with sugarcane $(180 \mathrm{~cm})+$ sweet sorghum 1:2 row (3.24). sugarcane $(150 \mathrm{~cm})+$ sweet potato with 1:2 row proportion recorded significantly higher LER (1.47) and found at par with sugarcane $(180 \mathrm{~cm})+$ sweet potato with 1:2 row proportion (1.44). Sugarcane $(150 \mathrm{~cm})+$ Sugarbeet with 1:2 row proportion recorded significantly higher ATER (1.18)

\section{References}

Anonymous, 2013, Directorate of Sugarcane Development, Status paper on sugarcane Ministry of Agriculture, Govt. of India.

Anonymous, 2016 a, Ministry of Agriculture, Govt. of India. www.indiastat.com

Anonymous, 2017, Ministry of Agriculture, Govt. of India. www.indiastat.com

Hiebsch, C. and McCollum, R. E., 1987, Area $\times$ time equivalency ratio: A method for evaluating the productivity of intercrops. Agron. J., 79: 15-22.

McGilchrist, C. A. and Trenbath, B. R., 1971, A revised analysis of plant competition experiments. Biometrics, 27: 659-671.

Willey, R. W. and Rao, M. R, 1980, A competitive ratio for quantifying competition between intercrops. Exp. Agric., 16: 117-125.

Willey, R. W. and Ruberts, E. M., 1979, Mixed cropping. Advances in Agron., 28: 185-192.

Willey, R. W., 1979, Intercropping-its importance and research needs. Part 1. Competition and yield advantage. Field Crop Abst., 32: 1-10.

\section{How to cite this article:}

Shilpa V. Chogatapur, H.T. Chandranath and Khandagave, R.B. 2018. Economics and Intercropping Indices of Sugarcane Based Intercropping System in Plant Cane. Int.J.Curr.Microbiol.App.Sci. 7(08): 101-107. doi: https://doi.org/10.20546/ijcmas.2018.708.012 